\begin{tabular}{c} 
Volume and Issues Obtainable at Center for Sustainability Research and Consultancy \\
Journal of Business and Social Review in Emerging Economies \\
ISSN: 2519-089X (E): 2519-0326 \\
Volume 6: No. 1, March 2020 \\
CSRᄃ \\
Journal homepage: www.publishing.globalcsrc.org/jbsee \\
\hline $\begin{array}{c}\text { Profit } \\
\text { PSlanet }\end{array}$
\end{tabular}

\title{
Prevalence and Prevention Strategies of Violence in Special Schools: A Quantitative Survey
}

\section{${ }^{1}$ Rukhsana Bashir, ${ }^{2}$ Ghulam Fatima, ${ }^{3}$ Samina Ashraf}

${ }^{1}$ Assistant Professor, Department of Special Education, University of the Punjab, Lahore, Pakistan: rukhsana.dse@gmail.com

${ }^{2}$ Associate Professor, Institute of Education and Research, University of the Punjab, Lahore, Pakistan: fatima.ier@pu.edu.pk

${ }^{3}$ Assistant Professor, Department of Special Education, University of the Punjab, Lahore, Pakistan: miss_saminadse@yahoo.com

\begin{tabular}{l} 
ARTICLE DETAILS \\
\hline History \\
Revised format: February 2020 \\
Available Online: March 2020
\end{tabular}

Keywords

Prevalence, Verbal And Non-

Verbal Violence, Students With

Hearing Impairment,

Prevention Strategies

\section{JEL Classification:}

C40, J14

\section{ABSTRACT}

This study was carried out to identify the opinions of students with hearing impairment and their teachers about prevalence of violence in special schools. This research was quantitative in nature and descriptive research method was used to conduct the study. The population of the study comprised students with hearing impairment (SWHI) and their teachers working in public sector schools. Researchers selected 60 students with hearing impairment studying at elementary level $($ males $=23$, females $=37)$. A sample of 100 teachers were also taken from schools working in Lahore. On the basis of literature review, two structured questionnaires with close ended options were developed. The estimated reliability of teachers' questionnaire was Cronbach alpha 0.82 and of students' questionnaire (Cronbach alpha 0.85). Researchers personally visited schools to collect data from students whereas data from teachers were collected through telephone and email. Frequency percentages, mean and standard deviation were used for data analysis. The results of the study indicated that most of students with hearing impairment used to experience non- verbal violence and feel scary before and after school time. Teachers reported that students used to threaten one another, damage school property or personal items. They used abusive language. Schools had taken many initiatives to create healthy and safe environment i.e, appointing security guards to control access to school buildings, increasing monitoring by applying rules and regulations and involving students in conflict resolving activities. However, training teachers, counselling, student tutoring and mentoring are required for healthy school environment. (C) 2020 The authors, under a Creative Commons Attribution-

NonCommercial 4.0

Corresponding author's email address: rukhsana.dse@ gmail.com

Recommended citation: Bashir, R., Fatima, G. \& Ashraf, S., (2020). Prevalence and Prevention Strategies of Violence in Special Schools: A Quantitative Survey. Journal of Business and Social Review in Emerging Economies, 6(1), 75-80

DOI: $10.26710 /$ jbsee.v6i1.1030 


\section{Introduction}

Violence is a complex phenomenon initiated through various isolated or simultaneous actions, which can employ at one or more different levels from the physical to the verbal, emotional and sexual (Jevtic et al., 2014; Padurariu et al., 2016; Berlanda et al., 2019). The literature discusses four main kinds of violence, emotional, physical, sexual and psychological abuse and neglect (Sakelliadis, Spiliopoulou, \& Papadodima, 2009; WHO, 2006, 2002). Violence has been recognized as a more extensive issue and global phenomenon (Moore, Jones, \& Broadbent, 2008; Jimerson, Nickerson, Mayer, \& Furlong, 2012). United Nations International Children's Education Fund (UNICEF) has emphasized facets of these phenomena in a study "Violence against Children", and recognized its complexities and effects on emotional health of students (Pinheiro, 2006).

Violence in schools is one of the most observable forms of violence against children. Bullying, physical violence, gender biasness, sexual harassment, and psychological violence describe some of the prevailing forms of school-based violence. It creates threatening environment, insecurity and fear which harms the school climate and pupils' right to learn in a safe and healthy environment. Capozzoli and McVey (2000) reported that school violence was rare but with the passage of time it has increased. Violence against children is a global problem. UNESCO (2019) documented that violence in schools and bullying are major problems worldwide. It demonstrates that despite the severity of the problem, some countries have made significant progress towards reducing school violence. A review of 53 studies found that incidence of violence has reduced at all grade levels respectively $32 \%$ for kindergarten, $29 \%$ high school and $18 \%$ for elementary school students by implementing universal school-based violence prevention programs. These programs also seemed to be useful in reducing violent behavior among students regardless of their race, ethnicity, socioeconomic status, or crime rate (Farrington \& Baldry, 2010).

There is growing prevalence that rate of violence is increasing in developing countries (Leach, Dunne, \& Salvi, 2014; UNESCO, 2015; UNGEI \& UNESCO, 2013), and numerous young people face violence in various domains of their lives (Chisamya et al., 2012; Pinheiro, 2006). Children exposed to violence exhibit more behavioral problems than non-victimized children (Martinez-Torteya, Bogat, Eye, \& Levendosky, 2009). It is reported that violence-related events are increasing in Pakistan as well. Incidence of various kinds of violence were common among young adults attending secondary high schools of Lahore, Quetta and Karachi. Youngsters reported high rate of violence like verbal and physical abuse, serious injury and being bullied (Hyder \& Malik, 2007).

Government of Pakistan has signed many international conventions, showing their obligation to the cause of elimination of all forms of inequalities and prejudice against children and particularly girls and women. Despite of initiatives carried out to address the violence in schools, it remains a serious issue and emerging concern. This draw a conclusion that procedures and plans designed to avoid violence have not yet turn out completely effective. School violence is not limited to regular schools; it is reported in special schools as well. So, it can be considered as a key risk factor and magnitude of social exclusion and vulnerability. Review of recent studies indicated that incidence of violence was three to four times greater among children with disabilities than children without disabilities (Wood, Eckley, \& Mikton, 2012).

\section{Objectives of the Study}

The study was conducted to:

1. Identify the various forms of violence experienced by students with hearing impairment enrolled in special schools.

2. Examine the opinions of teachers of students with hearing impairment about violence in special schools.

3. Identify the prevention strategies adopted by schools to overcome violence in special schools. 


\section{Research Methodology}

The nature of study was quantitative and descriptive research method was employed to complete the study. Researchers have followed the following procedure to complete the study:

\section{Population and Sample of the Study}

The target population of the study was students with hearing impairment (SWHI) and their teachers working in public sector schools. Researchers selected four schools randomly and a sample of 60 SWHI (15 from each school) studying at elementary level (males $=23$, females $=37$ ). A sample of 100 teachers (males $=18$, females $=82$ ) were taken conveniently from 07 schools working for SWHI in Lahore city. The students were enrolled in elementary classes (grade 6:23, grade 7: 19, grade 8: 18), having hearing loss from moderate to severe. The qualification of teachers was ranging from Masters to PhD (Master:72, Mphil:25, PhD:03),

\section{Instrument}

After reviewing the related literature on the topic under study, two questionnaires with close ended options were developed. First questionnaire discussed the types of violence in schools and second questionnaire was used for teachers with following three major components:

1. General opinion about violence in special schools

2. Type of violence in schools

3. Prevention strategies adopted by schools

Content validity of both questionnaires was checked by a panel of three experts. The reliability of teachers' questionnaire was 0.82 and student's questionnaire 0.85 (Cronbach Alpha).

\section{Data Collection and Analysis Procedure}

After obtaining formal consent from the concerned schools, the questionnaires were administered. The statements of the students' questionnaire were interpreted to hearing impaired students by using sign language and their responses were reported on scale. Researchers rated their scale by themselves. Researchers personally visited schools to collect data from students whereas data from teachers were collected through telephone and email. Frequency distribution and descriptive statistics were used for data analysis.

\section{Results}

\section{Table 1}

Frequency distribution of students' responses

\begin{tabular}{llll}
\hline $\begin{array}{l}\text { Sr. } \\
\text { No }\end{array}$ & Statements & Yes $\%$ & No\% \\
\hline 1. & Physical violence & $05 \%$ & $95 \%$ \\
2. & Teachers scream upon them & $61 \%$ & $39 \%$ \\
3. & Feel safe in school before time and after school time & $16 \%$ & $84 \%$ \\
4. & Incidence of sexual abuse made them scary & $76 \%$ & $24 \%$ \\
5. & Negative attitude of non-teaching staff & $80 \%$ & $20 \%$ \\
\hline
\end{tabular}

\section{Table 2}

Mean and SD of teachers' responses

\begin{tabular}{llll}
\hline Sr. & Statements & Mean & SD \\
No & & \\
\hline 1. & Violence is a problem at my school. & 3.14 & 1.06 \\
2. & $\quad$ Incidence of violence has increased in special schools & 2.89 & 1.26 \\
& & \\
during the last 5 years. & 3.01 & 1.89 \\
4. $\quad$ I am worried about personal safety of students. & 3.15 & 1.07
\end{tabular}


5. Most of the violence cases are unreported due to social 2.99

stigma.

\section{Type of violence}

$\begin{array}{lll}\text { 1. Name calling, insulting and teasing } & 2.70 & 1.04\end{array}$

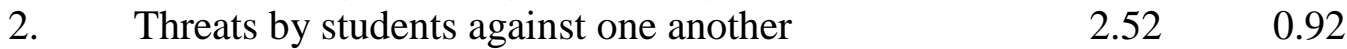

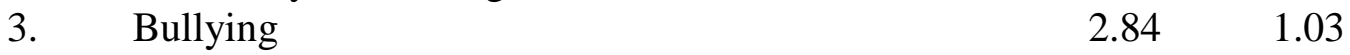

$\begin{array}{lll}\text { 4. Sexual comments/signs } & 2.25 & 0.89\end{array}$

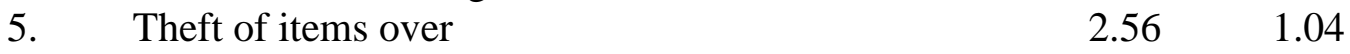

$\begin{array}{lll}\text { 6. Students' drug use } & 1.61 & 0.75\end{array}$

$\begin{array}{llll}7 . & \text { Students' tobacco use } & 1.70 & 0.76\end{array}$

$\begin{array}{lrr}\text { 8. Verbal abuse of teachers } & 1.75 & 0.83\end{array}$

$\begin{array}{lll}\text { 9. Physical abuse of teachers } & 1.75 & 0.86\end{array}$

10. Students Gangs (gang violence in school) $\quad 2.95 \quad 1.83$

$\begin{array}{lll}\text { 11. Boys and girls are involved with one another } & 1.95 & 0.83\end{array}$

$\begin{array}{llll}\text { 12. Students damage school property or personal items. } & 2.54 & 1.08\end{array}$

$\begin{array}{lll}\text { 13. Students use abusive language. } & 2.47 & 0.97\end{array}$

$\begin{array}{lll}\text { 14. Rape or other type of sexual activities } & 2.20 & 1.04\end{array}$

$\begin{array}{lll}\text { 15. Students involved in sexual acts } & 1.59 & 0.75\end{array}$

16. Non-teaching staff such as divers, helpers etc touch
badly to girls

$\begin{array}{lll}\text { 17. Non-teaching staff show sexual pictures or videos } & 1.75 & 0.81\end{array}$

\section{Table 3}

Showing percentage of frequent and less used prevention strategies by special schools

\begin{tabular}{lll}
\hline $\begin{array}{l}\text { Sr. } \\
\text { No }\end{array}$ & Prevention Strategies & $\begin{array}{c}\% \text { of frequent used } \\
\text { strategies }\end{array}$ \\
\hline 1. & Apply school code of behavior & $92 \%$ \\
2. & Make and implement Classroom rules & $85 \%$ \\
3. & Enforce positive school environment & $94 \%$ \\
4. & Teacher monitor & $79 \%$ \\
5. & Guards for school security & $100 \%$ \\
6. & Safe school grounds & $100 \%$ \\
7. & Controlled access to school buildings & $100 \%$ \\
8. & At lunch time school gate is closed & $100 \%$ \\
9. & Students remain in school grounds for lunch & $82 \%$ \\
10. & Teachers' supervision during break & $88 \%$ \\
11. & Behavior modification for students & $74 \%$ \\
12. & Leisure activities for students & $69 \%$ \\
13. & Involvement of students in resolving conduct & $72 \%$ \\
& problems. & \\
Prevention Strategies & of & less \\
& & used \\
1. & Suspension & $12 \%$ \\
2. & Expulsion & $14 \%$ \\
3. & Principal/vice Principal monitoring & $40 \%$ \\
4. & Parental involvement & $33 \%$ \\
5. & Conflict resolution strategies & $29 \%$ \\
6. & Police involvement & $2 \%$ \\
7. & In-service training on violence prevention strategies \\
8. & Prevention curriculum or training for students \\
9. & Counseling and therapeutic activity for students & $7 \%$ \\
& & $33 \%$ \\
& $18 \%$
\end{tabular}


10.

\section{Discussion on Major Findings}

Students with hearing impairment (95\%) reported that incidence of physical violence was rare in special schools whereas $(61 \%)$ of SWHI reported that teachers did scream upon them and sometimes used to make them realize that they could not perform up to the mark. It is surprising to note that special education teachers who are imparted training in dealing with special need students and who are recruited after a rigorous process, indulge themselves in screaming and teasing students with hearing impairment. Students with hearing impairment (84\%) also reported that they did not feel safe in school before and after school time and incidence of sexual abuse in another school had made them scary (76\%). The attitude of students with hearing impairment regarding their safety within the premises of their schools is alarming and sufficient to draw the attention of school authorities towards adopting security measures for these children.

Majority of students with hearing impairment (80\%) reported that attitude of non-teaching staff was negative toward them and they sometimes used to make bad comments on them. It is again a matter of great concern which reflects that non-teaching staff is not being monitored and students with hearing impairment are either not submitting their complaints to the administration. Majority of teachers (Mean: 3.14) reported that violence was a problem in their schools and incidence of violence had increased in special schools within the last five years. Majority of teachers reported that they used to get worried about personal safety of students (Mean: 3.01). They also reported that school based violence in Pakistan is increasing day by day (Mean :3.15). This major finding may be supported by conducting more in depth qualitative studies to explore the root causes of this increasing school based violence in Pakistan. It was also explored during data collection from special education teachers that most of the violence cases were unreported due to social stigma (Mean:2.99). The reason lies in the cultural and social constraints which do not allow a common individual to disclose his personal disgrace or abuse which results in further humiliating and degrading attitude of society members towards him.

Teachers reported occasional incidence of violence such as students threatening one another, theft of items over, students damaging school property or personal items, using abusive language and gang violence in schools. Teachers reported about rare incidences of violence such as calling names, insulting and teasing, using drugs and tobacco, verbal and physical abuse by teachers and use of weapons by students. Majority of teachers reported that school had framed code of behaviors, and classroom rules, enforced positive school environment, and controlled access to school buildings. Teachers used to make supervise visits during lunch time, arrange leisure activities for students and involve students in resolving conduct problems. Teachers stated that some prevention strategies were being used by special schools on a limited scale such as suspension, expulsion, principals' monitoring, parental involvement, counseling or therapeutic activity for students, in-service training on prevention strategies and curricular activities for students.

\section{Implications for Practice}

Small scale researches conducted in Pakistan reported that Pakistan is one of 92 countries trying to eliminate corporal punishment in public, private and religious institutions. This practice has been reduced due to legal sanction under Section 89 of Pakistan Penal Code. So, it is recommended that strong legislative support is required to control other types of violence i.e psychological, emotional and sexual violence in schools and rest of social settings.

Special teachers and psychologists may initiate partnership and start dialogues with teachers/students/parents to help out victimized students with hearing impairment. Teachers can play an essential role in sensitizing students with hearing impairment about increasing incidence of sexual violence by showing different documentaries. Principals of schools may re-activate disciplinary 
committees to see into the matter of students fighting with another, harassment and sexual abuse events. Department of Special Education, Government of Punjab, may conduct surveys to further look into the severity of incidences of violence in the special schools and solid measures should be taken to control this phenomenon.

\section{Reference}

Berlanda S., Pedrazza M., Trifiletti E., Fraizzoli., M. (2017). Dissatisfaction in child welfare and its role in predicting self-efficacy and satisfaction at work: a mixed-method research. Biomed Res. Int.

Capozzoli, T. K., \& McVey, R. S. (2000). Kids killing kids: Managing violence and gangs in schools. Boca Raton, FL: St. Lucie Press.

Farrington, D., Baldry, A. (2010). Individual risk factors for school bullying. Journal of Aggression, Conflict and Peace Research. Volume2(1), Retrieved from www.researchgate.net.

Jimerson, S. R., Nickerson, A., \& Furlong, M. J. (2012). Handbook of school violence and school safety: International research and practice. University of California, Santa Barbara 187 Publications.

Jevtic B., Petrovic Z. S., Stankovic A. Z. (2014). Victims or bullies-students or teachers. Procedia Soc. Behav. Sci. 141 587-596. 10.1016/j.sbspro.2014.05.103

Leach, F. Dunne, M., Salvi, F. (2014). Background research paper prepared for UNESCO. School-related gender-based violence: A global review of current issues and approaches in policy, programming and implementation responses to school-related gender-based violence (SRGBV) for the education sector. [Google Scholar]

Malik, F, A., \& Hyder, A (2007). Violence against children in Pakistan: quantitative estimates. Retrieved from www.researchgate.net/figure/Violence-against-children-in-Pakistan-quantitativeestimates tbl4_5860580

Martinez-Torteya, C., Bogat, G. A., Eye, A. V., \& Levendosky, A. A. (2009). Resilience among children exposed to domestic violence: The role of risk and protective factors. Child Development, 80(2), 562-577.

Moore, K., Jones, N., \& Broadbent, E. (2008). School violence in OECD countries. London: Plan International.

Padurariu M., Prepelita R., Ciobica A., Dobrin R., Timofte D., Stefanescu C., et al. (2016). Short review on the aggressive behaviour: genetical, biological aspects and oxytocin relevance. Int. Lett. Nat. Sci. 52 43-53. 10.18052/www.scipress.com/ilns.52.43

Pinheiro, P. (2006). Report of the independent expert for the United Nations study on violence against children. New York: United Nations.

Sternberg, K. J., Lamb, M. E., Guterman, E., \& Abbott, C. B. (2006). Effects of early and later family violence on children's behavior problems and depression: A longitudinal, multi-informant perspective. Child Abuse \& Neglect, 30(3), 283-306.

UNESCO. (2019). School violence and bullying a major global issue. Retrieved from en.unesco.org

UNESCO. (2015). Education for All Global Monitoring Report. Education for All 2000-2015: Achievements and challenges. [Google Scholar]

UNGEI, \& UNESCO. (2013). Discussion Paper. School-related gender-based violence. [Google Scholar]

Wood, S., Eckley, L., \& Mikton, C. (2012). Prevalence and risk of violence against children with disabilities: a systematic review and meta-analysis of observational studies. Retrieved from www.ncbi.nlm.nih.gov/pubmed/22795511

World Health Organization. (2012). Retrieved from the who.int/about/licensing/copyright form/en/index.html). 